Published in final edited form as:

Org Lett. 2016 May 06; 18(9): 2296-2299. doi:10.1021/acs.orglett.6b00942.

\title{
Enantioselective Total Synthesis of (+)-Amphirionin-4
}

\author{
Arun K. Ghosh ${ }^{*}$ and Prasanth R Nyalapatla \\ Department of Chemistry and Department of Medicinal Chemistry, Purdue University, 560 Oval \\ Drive, West Lafayette, Indiana, 47907, United States
}

\begin{abstract}
An enantioselective total synthesis of (+)-amphirionin- 4 has been accomplished in a convergent manner. The synthesis features an efficient enzymatic lipase resolution to access the tetrahydrofuranol core in optically-active form. The functionalized tetrahydrofuran derivative was synthesized via an oxocarbenium ion-mediated highly diastereoselective syn-allylation reaction. The polyene side chain was synthesized using Stille coupling reactions. Nozaki-Hiyama-Kishi coupling was utilized to construct the C-8 stereocenter and complete the synthesis of (+)amphirionin-4.
\end{abstract}

\section{Graphical Abstract}<smiles>C=CCC/C=C\C=C(/C)CC(=C)/C=C(\C)CC[C@@H](O)C(=C)C[C@@H]1O[C@H](C)C[C@H]1O</smiles>

Marine dinoflagellates of the genus Amphidiuium species are rich sources of bioactive polyketide-like natural products with intriguing biological properties. ${ }^{1,2}$ Recently, Tsuda and co-workers isolated a number of polyketides, amphirionins-2, -4 and -5 from the dinoflagellate Amphidiuium species. ${ }^{3,4,5}$ Among these, the linear polyke-tide (+)amphirionin-4 (1, Figure 1) was isolated from the Amphidiuium KCA09051 strain in the benthic sea sand collected off the Iriomote Island. This compound exhibited exceptionally potent proliferation-promoting activity (95\% promotion) on murine bone marrow stomal ST-2 cells at $0.1 \mathrm{ng} / \mathrm{mL}$ concentration. Interestingly, it did not show proliferation promotion when administered to MC3T3-E1 and NIH3TC cells. ${ }^{4}$

*Corresponding Author: akghosh@purdue.edu.

Supporting Information

Experimental procedures and ${ }^{1} \mathrm{H}$ - and ${ }^{13} \mathrm{C}$ - NMR spectra are available for all new compounds. This material is available free of charge via the Internet at http://pubs.acs.org. 
The structure of (+)-amphirionin-4 was elucidated by Tsuda and co-workers using extensive NMR analysis and the absolute configuration of the $\mathrm{C} 4$ and $\mathrm{C} 8$ hydroxyl groups was determined by Mosher ester analysis. ${ }^{4}$ Recently, Britton and co-workers have reported the first synthesis of amphirionin-4. ${ }^{6}$ However, the specific rotation of the synthetic compound was opposite to that reported for natural amphirionin- $4 .{ }^{4,6}$ Considering the intense proliferation-promotion activity of (+)-amphirionin-4 in ST-2 cells, its structural features, and its potential medicinal application, we sought to develop a convergent and concise enantioselective synthesis of (+)-amphirionin-4. Herein, we now report a route that proceeds in 9 linear steps, starting from a readily available racemic butyrolactone.

Our retrosynthesis of (+)-amphirionin-4 is shown in Figure 1. We planned to utilize a Nozaki-Hiyama-Kishi (NHK) ${ }^{7,8}$ reaction similar to that reported by Britton and coworkers $^{6}$ to assemble amphirionin- 4 from vinyl iodide $\mathbf{2}$ and polyene aldehyde $\mathbf{3}$ at a late stage in the synthesis. The functionalized tetrahydrofuran ring $\mathbf{2}$ would be constructed from optically active $\boldsymbol{\gamma}$-lactone $\mathbf{4}$ via a cis-selective allylation of the corresponding oxocarbenium ion derived from lactone $\mathbf{4}$. Optically active lactone $\mathbf{4}$ would be readily synthesized via acidcatalyzed condensation of pyruvic acid and acetaldehyde, followed by hydrogenation and lipase-catalyzed optical resolution of racemic lactone. This will provide rapid access to both enantiomers for structure-activity relationship studies of amphirionin-4. The polyene side chain 3 would be constructed by Julia-Kocienski olefination of the aldehyde derived from allylic alcohol 5. ${ }^{9}$ The requisite aldehyde precursor would be synthesized by iterative Stille cross-coupling reactions with appropriately protected vinyl iodide $\mathbf{6}$, and tributylstannanes $\mathbf{7}$ and 8 .

Our synthesis of functionalized tetrahydrofuran derivatives is shown in Scheme 1. Racemic lactone $\mathbf{4}$ was synthesized on gram scale by acid-catalyzed condensation of pyruvic acid $\mathbf{9}$ and acetaldehyde, followed by hydrogenation of the resulting unsaturated lactone over $10 \%$ Pd-C in EtOAc. ${ }^{10,11}$ Racemic lactone $\mathbf{4}$ was then subjected to enzymatic resolution utilizing PS-30 in vinyl acetate at $23{ }^{\circ} \mathrm{C}$ for 5 h. ${ }^{12,13}$ While the racemic lactone was obtained in low yield, it can be readily prepared in gram quantity and the current resolution protocol provided optically active alcohol (+)-4 and acetate derivative 10 in $47 \%$ and $50 \%$ yields, respectively, with high optical purity. Acetate $\mathbf{1 0}$ was saponified with aqueous sodium hydroxide in methanol to provide optically active alcohol (-)-4 in $82 \%$ yield. ${ }^{14}$ The depicted absolute stereochemistry of lactones (+)-4 and (-)-4 was assigned based upon Kazlauskas' model ${ }^{15}$ and comparison with the reported specific rotations. ${ }^{16}$ Optically active lactone (-)-4 was protected as the benzyl ether (>90\% ee by chiral HPLC analysis of this benzyl derivative). Dibal-H reduction of the protected lactone provided the corresponding lactol, which was treated with acetic anhydride and pyridine in the presence of DMAP to provide acetate $\mathbf{1 1}$ in excellent yield. The hydroxyl group of lactone (-)-4 was also protected as the TBS ether. Dibal-H reduction of that lactone provided a mixture of lactols, which were converted to the acetate 12. The reaction of acetate 11, bearing a $\mathrm{C} 2$ benzyl ether, with allyltrimethylsilane in the presence of $\mathrm{SnBr}_{4}$ in $\mathrm{CH}_{2} \mathrm{Cl}_{2}$ at $-78{ }^{\circ} \mathrm{C}$ to $23{ }^{\circ} \mathrm{C}$ provided the allyl derivatives $\mathbf{1 3}$ and $\mathbf{1 4}$ as a 3:1 mixture of diastereomers by ${ }^{1} \mathrm{H}-\mathrm{NMR}$ analysis. The corresponding reaction of acetate $\mathbf{1 2}$ containing a $\mathrm{C} 2$ silyl ether with allyltrimethylsilane under similar conditions furnished allylation products $\mathbf{1 5}$ and $\mathbf{1 6}$ in 80\% yield. However, the 
diastereomeric ratio of $\mathbf{1 5}$ and $\mathbf{1 6}$ improved to 10:1 (by ${ }^{1} \mathrm{H}$ NMR analysis). The relative stereochemistry of alkenes $\mathbf{1 3}, \mathbf{1 4}$, and $\mathbf{1 5}$ was assigned by ${ }^{1} \mathrm{H}$ NMR NOESY analysis.

The observed cis-diastereoselectivity is consistent with a C2-benzyloxy substituted tetrahydrofuranyl substrate examined by Woerpel and co-workers. ${ }^{17}$ It appears that substituents at the C4-position, as in acetate 11, did not influence overall cisdiastereoselectivity. The observed stereochemical outcome can be rationalized using similar steric and electronic arguments to those proposed by Woerpel and co-workers. ${ }^{17}$ Presumably, the oxocarbenium ion intermediate $\mathbf{1 7}$ is preferred over $\mathbf{1 8}$ due to pseudoequatorial orientation of the $\mathrm{C}-2$ alkoxy group. The $\sigma \mathrm{C}-\mathrm{H}$ orbital at $\mathrm{C} 2$ maximizes electron donation to the adjacent vacant orbital of the oxocarbenium ion. The bulky $\mathrm{C} 2$ siloxy group further enhances the pseudoequatorial orientation, and therefore the overall cisselectivity.

The desired allyl derivative $\mathbf{1 5}$ was converted to the corresponding vinyl iodide as shown in Scheme 2. Oxidative cleavage of alkene 15 using $\mathrm{PhI}(\mathrm{OAc})_{2}, \mathrm{NMO}$ and catalytic $\mathrm{OsO}_{4}$ provided the corresponding aldehyde in $80 \%$ yield. ${ }^{18}$ Alkynylation of the resulting aldehyde with the Ohira-Bestmann reagent ${ }^{19,20}$ and $\mathrm{MeONa}$ in a mixture of $\mathrm{MeOH}$ and THF gave alkyne 20 in 70\% yield. Hydrosilylation of the resulting alkyne $\mathbf{2 0}$ using Trost's procedure ${ }^{21}$ with $\left(\left[\mathrm{CpRu}(\mathrm{MeCN})_{3}\right] \mathrm{PF}_{6}\right)$ and triethylsilane followed by iododesilylation ${ }^{22}$ with NIS and 2,6-lutidine in hexafluoroisopropanol furnished vinyl iodide 2 in $80 \%$ yield.

Synthesis of the side chain $\mathbf{5}$ is shown in Scheme 3. A zirconium-catalyzed carboalumination of 4-pentyne-1-ol 20 followed by reaction with iodine provided the corresponding vinyl iodide. TBS protection of the alcohol provided the vinyl iodide $\mathbf{2 1}$ in $91 \%$ yield. ${ }^{23}$ We then investigated the Stille coupling of vinyl iodide 21 with the known ${ }^{24}$ tributylstannane 7 under a variety of conditions. The results are summarized in Table 1. Reactions with $\mathrm{Pd}(\mathrm{MeCN})_{2} \mathrm{Cl}_{2}\left(10\right.$ or $20 \mathrm{~mol} \%$ ) in DMF at $23{ }^{\circ} \mathrm{C}$ resulted in $30 \%$ yield (entries 1 and 2). Catalyst loading was then increased to $30 \mathrm{~mol} \%$ and reaction temperature was increased to $50{ }^{\circ} \mathrm{C}$ for $96 \mathrm{~h}$. This resulted in low yield of coupling product 22 (entry 3). Coupling with $\mathrm{Pd}_{2}(\mathrm{dba})_{3}(30 \mathrm{~mol} \%)$ at $23{ }^{\circ} \mathrm{C}$ in a mixture of DIPEA/NMP also resulted in low yield of product ( $25 \%$, entry 4). We believe that these low yields can be attributed to the disubstituted vinylstannane, due to a slow transmetallation step and a competing cine substitution. ${ }^{25}$ In an attempt to enhance the transmetallation step, we decided to use cuprous chloride as a promoter in the Stille-coupling reactions as described by Corey and coworkers. ${ }^{25}$ Modified Stille-coupling of vinyl iodide $\mathbf{2 1}$ and tributylstannane $\mathbf{7}$ in the presence of $\mathrm{CuCl}$ and $\mathrm{LiCl}$ at $23{ }^{\circ} \mathrm{C}$ for $2 \mathrm{~h}$ furnished the desired diene 22 in excellent (90\%) yield. Acetylation of diene $\mathbf{2 2}$ furnished the corresponding allyl acetate in $95 \%$ yield. Stillecoupling ${ }^{26}$ of the resulting allyl acetate with the known ${ }^{27}$ hydroxystannane 8 using $\operatorname{Pd}(\mathrm{dba})_{2}$ and $\mathrm{LiCl}$ in $\mathrm{DMF}$ at $50{ }^{\circ} \mathrm{C}$ afforded the coupling product in $96 \%$ yield. $\mathrm{MnO}_{2}$ oxidation of the resulting allylic alcohol furnished the aldehyde $\mathbf{2 3}$ in $80 \%$ yield.

Our synthesis of the polyene derivative $\mathbf{3}$ is shown in Scheme 4. Sulfone $\mathbf{2 6}$ was prepared in good yield by the reaction of 4-penten-1-ol 24 with 1-phenyl- $1 H$-tetrazole-5-thiol 25, followed by oxidation using catalytic ammonium molybdate and hydrogen peroxide. JuliaKocienski olefination ${ }^{9}$ between aldehyde $\mathbf{2 3}$ and sulfone $\mathbf{2 6}$ gave the polyene 27 in $89 \%$ 
yield and only $E$-isomer was formed (by ${ }^{1} \mathrm{H}-\mathrm{NMR}$ analysis). Removal of the TBS group followed by DMP oxidation of the resulting alcohol provided aldehyde 3 in good yield.

The final synthesis of (+)-amphirionin-4 is outlined in Scheme 5. NHK coupling ${ }^{6}$ between aldehyde 3 and vinyl iodide 2 was carried out in DMF at $0{ }^{\circ} \mathrm{C}$ to $23{ }^{\circ} \mathrm{C}$ for $24 \mathrm{~h}$. This provided TBS-protected amphirionin- $4 \mathbf{2 8}$ as the major diastereomer (4:1) in $65 \%$ yield. The diastereomers were separated by silica gel chromatography. Deprotection of the TBS group using $70 \% \mathrm{HF}, 30 \%$ pyridine in the presence of excess pyridine furnished synthetic (+)-amphirionin-4 (1) in 98\% yield. The ${ }^{1} \mathrm{H}$ and ${ }^{13} \mathrm{C}$ NMR of our synthetic amphirionin-4 $\left\{[a]_{D}^{23}+6.4\left(c 0.08, \mathrm{CHCl}_{3}\right)\right\}$ are identical to the reported spectra for the natural (+)amphirionin- $4\left\{\right.$ Lit. $\left.^{4}[\mathrm{a}]_{\mathrm{D}}{ }^{20}+6\left(c 0.29, \mathrm{CHCl}_{3}\right)\right\}$, thus confirming the absolute configuration of our synthetic material.

In summary, we have achieved an enantioselective synthesis of (+)-amphirionin-4 (1). The synthetic route is convergent and readily scalable. The longest linear path was 9 steps from readily available racemic butyrolactone. The synthesis featured a lipase resolution of a racemic lactone to give highly optically pure isomers. Other key reactions include a highly diastereoselective syn-allylation reaction, an efficient Stille coupling to construct the polyene side chain and a NHK coupling to establish the C8 allylic alcohol diastereoselectively. Our synthesis will provide rapid access to (+)-amphirionin-4 (1) and structural variants for biological studies. Further investigations of structural and biological studies are in progress.

\section{Supplementary Material}

Refer to Web version on PubMed Central for supplementary material.

\section{Acknowledgments}

Financial support of this work was provided by the National Institutes of Health and Purdue University.

\section{References}

1. Kobayashi J, Tsuda M. Nat Prod. 2004; 21:77-93.(b) Kobayashi J, Kubota T. J Nat Prod. 2007; 70:451-460. [PubMed: 17335244]

2. Blunt JW, Copp BR, Hu W-P, Munro MHG, North-cote PT, Prinsep MR. Nat Prod Rep. 2008; 25:35-94. [PubMed: 18250897]

3. Kumagai K, Minamida M, Akakabe M, Tsuda M, Konishi Y, Tominaga A, Tsuda M, Fukushi E, Kawabata J. Bioorg Med Chem Lett. 2015; 25:635-638. [PubMed: 25534608]

4. Minamida M, Kumagai K, Ulanova D, Akakabe M, Konishi Y, Tominaga A, Tanaka H, Fukushi E, Kawabata J, Masuda A, Tsuda M. Org Lett. 2014; 16:4858-4861. [PubMed: 25188336]

5. Akakabe M, Kumagai K, Tsuda M, Konishi Y, Tominaga A, Tsuda M, Fukushi E, Kawabata J. Tetrahedron Lett. 2014; 55:3491-3494.

6. Holmes M, Kwon D, Taron M, Britton R. Org Lett. 2015; 17:3868-3871. [PubMed: 26172382]

7. Takai K, Kimura K, Kuroda T, Hiyama T, Nozaki H. Tetrahedron Lett. 1983; 24:5281-5284.

8. Jin H, Uenishi J, Christ WJ, Kishi Y. J Am Chem Soc. 1986; 108:5644-5646.

9. Blakemore PR, Cole WJ, Kocienski P, Morley A. Synlett. 1998; 1:26-28.

10. MaGee D, Mallais TC, Mayo PDM, Strunz GM. Tetrahedron. 2006; 62:4153-4161.

11. Kang HY, Ji Y, Yu YK, Yu JY, Lee Y, Lee SJ. Bull Kor Chem Soc. 2003; 24:1819-1826. 
12. Bianchi D, Cesti P, Battistel E. J Org Chem. 1988; 53:5531-34.

13. Ghosh AK, Chen Y. Tetrahedron Lett. 1995; 36:505-508.

14. Enders D, Sun H, Leusink FR. Tetrahedron. 1999; 55:6129-6138.

15. Bornscheuer, UT., Kazlauskas, RJ. Hydrolases in Organic Synthesis. Wiley-VCH; Weinheim, Germany: 1999.

16. Ahrens H, Paetow M, Hoppe D. Tetrahedron Lett. 1992; 33:5327-5330.

17. Larsen CH, Ridgway BH, Shaw JT, Smith DM, Woerpel KA. J Am Chem Soc. 2005; 127:1087910884. [PubMed: 16076193]

18. Nicolaou KC, Adsool VA, Hale CRH. Org Lett. 2010; 12:1552-1555. [PubMed: 20192259]

19. Ohira S. Synth Commun. 1989; 19:561-564.

20. Muller S, Liepold B, Roth GJ, Bestmann HJ. Synlett. 1996; 521-522

21. Trost BM, Ball ZT. J Am Chem Soc. 2005; 127:17644-17655. [PubMed: 16351094]

22. Llardi EA, Stivala CE, Zakarian A. Org Lett. 2008; 10:1727-1730. [PubMed: 18386904]

23. Zheng YF, Oehlschlager AC, Hartman PG. J Org Chem. 1994; 59:5803-5809.

24. Bellina F, Carpita A, Santis MD, Rossi R. Tetrahedron. 1994; 50:4853-4872.

25. Han X, Stoltz BM, Corey EJ. J Am Chem Soc. 1999; 121:7600-7605.

26. Valle LD, Stille JK, Hegedus LS. J Org Chem. 1990; 55:3019-3023.

27. Chellat MF, Proust N, Lauer MG, Stambuli JP. Org Lett. 2011; 13:3246-3249. [PubMed: 21612207] 

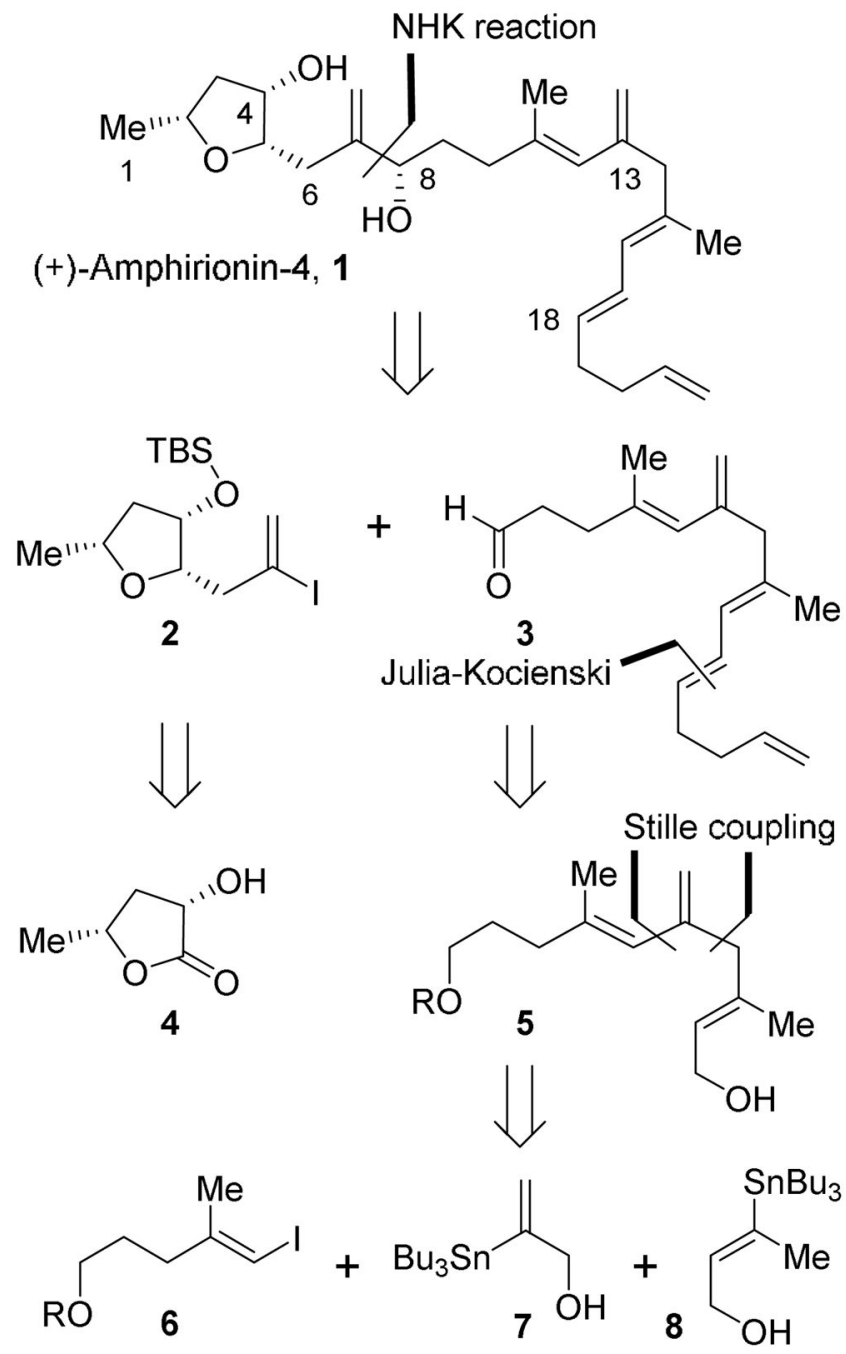

Figure 1.

Retrosynthetic analysis of (+)-amphirionin-4. 




Figure 2.

Stereochemical analysis for cis-allylation. 

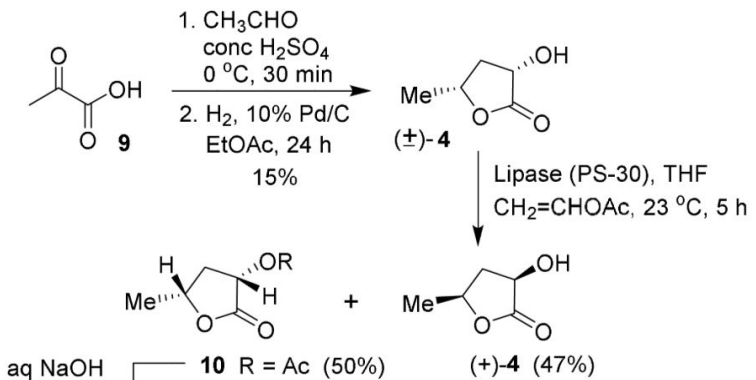

aq $\mathrm{NaOH}-10 \mathrm{R}=\mathrm{Ac}(50 \%) \quad(+)-4(47 \%)$

$23^{\circ} \mathrm{C}, 12 \mathrm{~h} \underset{82 \%}{\longrightarrow}(-)-4 \mathrm{R}=\mathrm{H}$

1. $\mathrm{BnBr}, \mathrm{Ag}_{2} \mathrm{O}, \mathrm{CH}_{2} \mathrm{Cl}_{2} \quad$ 1. TBSOTf, $\mathrm{CH}_{2} \mathrm{Cl}_{2}$

$94 \% \quad 23^{\circ} \mathrm{C}, 12 \mathrm{~h} \quad 92 \% \quad 2,6$-lutidine, $23^{\circ} \mathrm{C}, 1 \mathrm{~h}$

2. DIBAL-H, $-78^{\circ} \mathrm{C}, 2 \mathrm{~h} \quad$ 2. DIBAL-H, $-78^{\circ} \mathrm{C}, 2 \mathrm{~h}$

then $\mathrm{Ac}_{2} \mathrm{O}, \mathrm{Py} \quad$ then $\mathrm{Ac}_{2} \mathrm{O}, \mathrm{Py}$

$\downarrow$ DMAP, $0^{\circ} \mathrm{C}, 2 \mathrm{~h} \downarrow$ DMAP, $0^{\circ} \mathrm{C}, 2 \mathrm{~h}$

${ }^{\prime \cdots} \overbrace{O A C}$

11



$\mathrm{SnBr}_{4}$, AllyITMS, $\mathrm{CH}_{2} \mathrm{Cl}_{2}$

$-78^{\circ} \mathrm{C}$ to $23^{\circ} \mathrm{C}, 2 \mathrm{~h}$

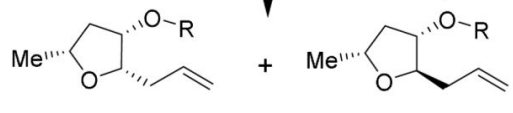

$13 \mathrm{R}=\mathrm{Bn} \quad 14 \mathrm{R}=\mathrm{Bn}$

$(79 \%, d r=3: 1)$

$15 \mathrm{R}=$ TBS $16 \mathrm{R}=\mathrm{TBS}$

$(80 \%, d r=10: 1)$

Scheme 1.

Synthesis of substituted tetrahydrofurans. 


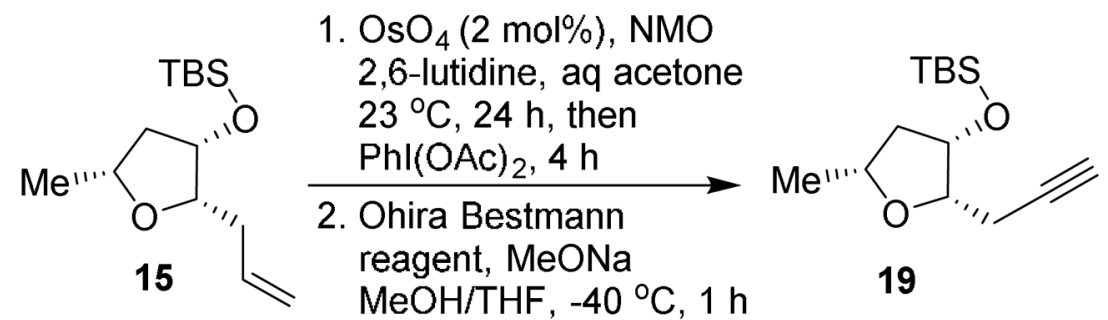

$\mathrm{MeOH} / \mathrm{THF},-40^{\circ} \mathrm{C}, 1 \mathrm{~h}$

$56 \%$

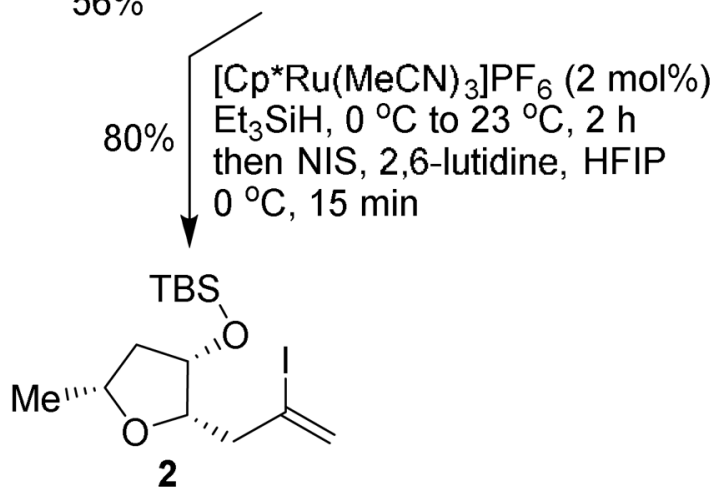

Scheme 2.

Synthesis of vinyl iodide 2. 


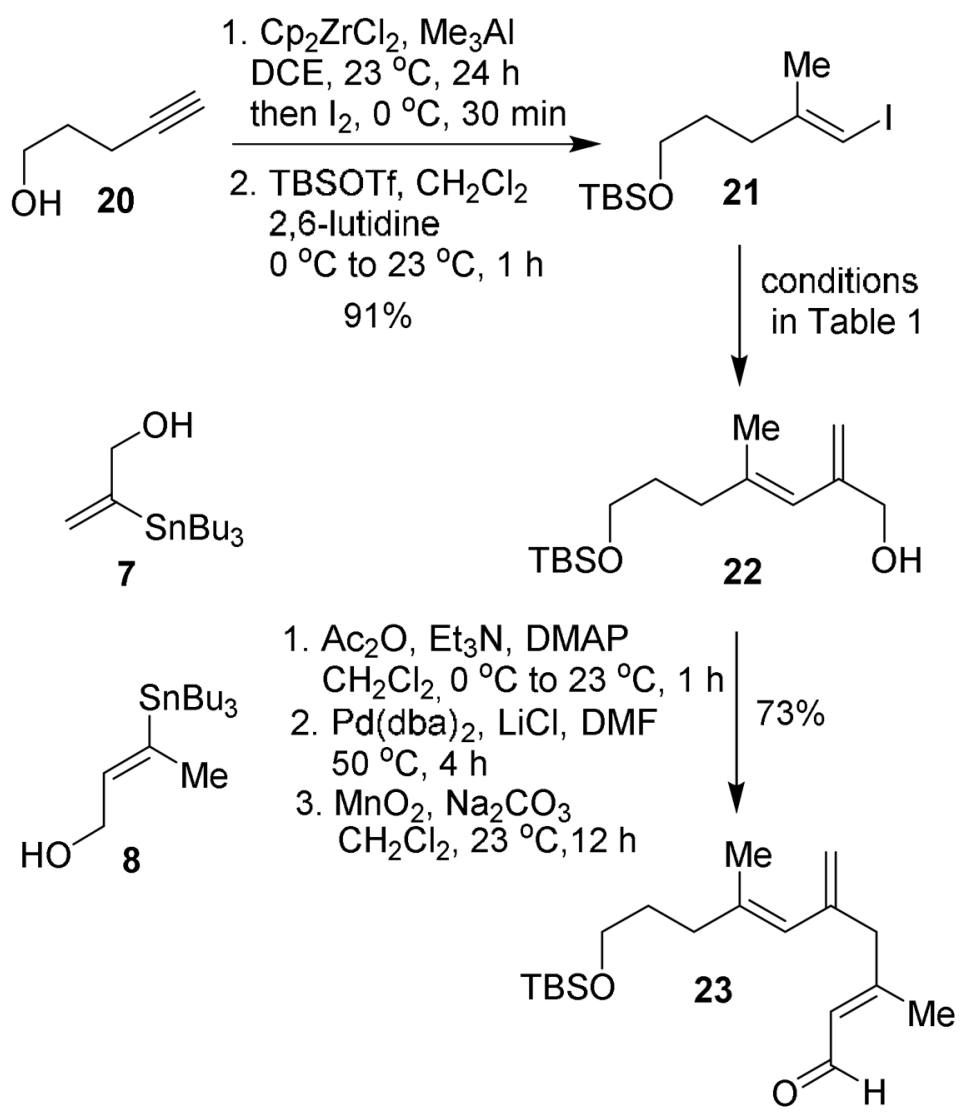

Scheme 3 .

Synthesis of aldehyde $\mathbf{2 3}$. 


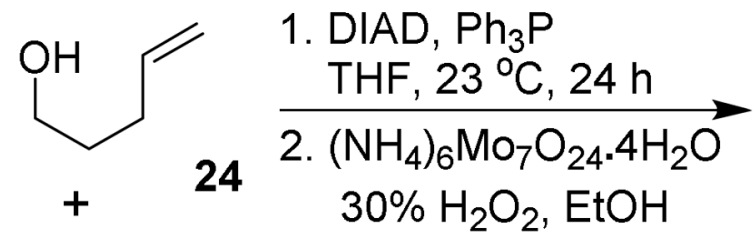<smiles>C=CCCCS(=O)(=O)c1nnnn1-c1ccccc1</smiles><smiles>Cn1nnnc1S</smiles>
$23^{\circ} \mathrm{C}, 12 \mathrm{~h}$ $80 \%$

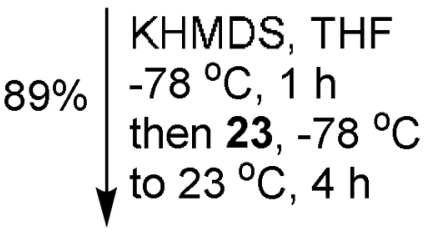<smiles>C=C(/C=C(\C)CCCO[AsH3])C/C(C)=C/C=O</smiles>

$\mathrm{Ph} 25$

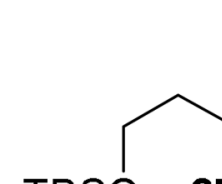<smiles>C=C(C=C(C)C)CCC</smiles><smiles>C=CCCC=C</smiles><smiles>C=CCC/C=C/C=C(\C)CC(=C)/C=C(\C)CCC=O</smiles>

Scheme 4.

Synthesis of aldehyde $\mathbf{3}$. 


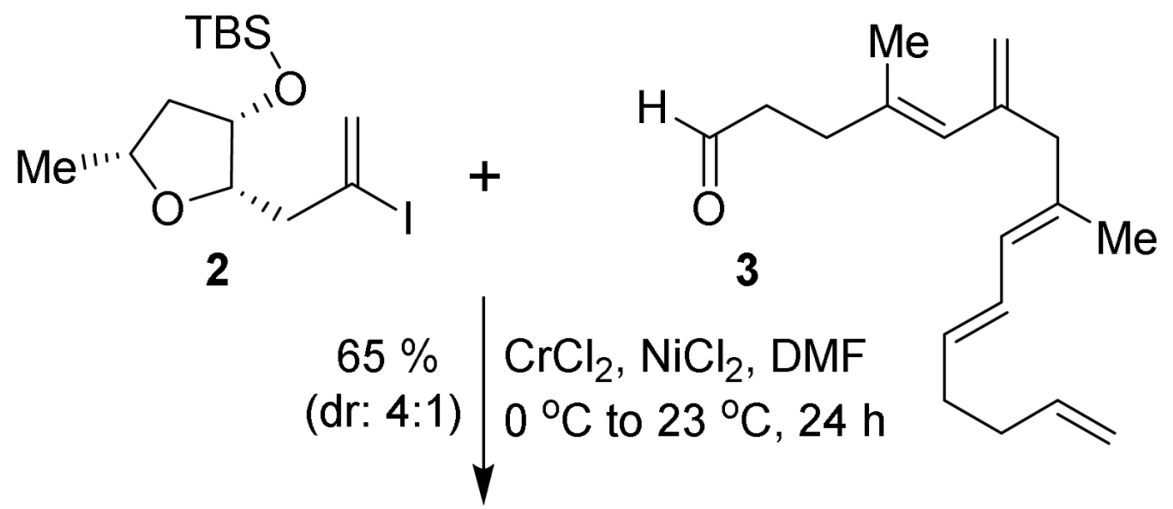<smiles>C=CCC/C=C/C=C(\C)CC(=C)/C=C(\C)CC[C@@H](O)C(=C)C[C@H]1O[C@H](C)C[C@H]1O[AsH3]</smiles><smiles>C=CCC/C=C/C=C(\C)CC(=C)/C=C(\C)CC[C@@H](O)C(=C)C[C@H]1O[C@H](C)C[C@H]1O[13CH3]</smiles>

Scheme 5.

Synthesis of (+)-Amphirionin-4 (1). 


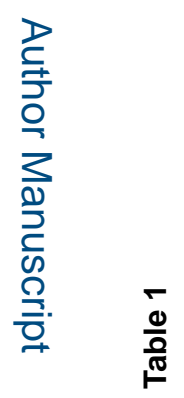

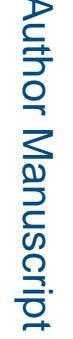

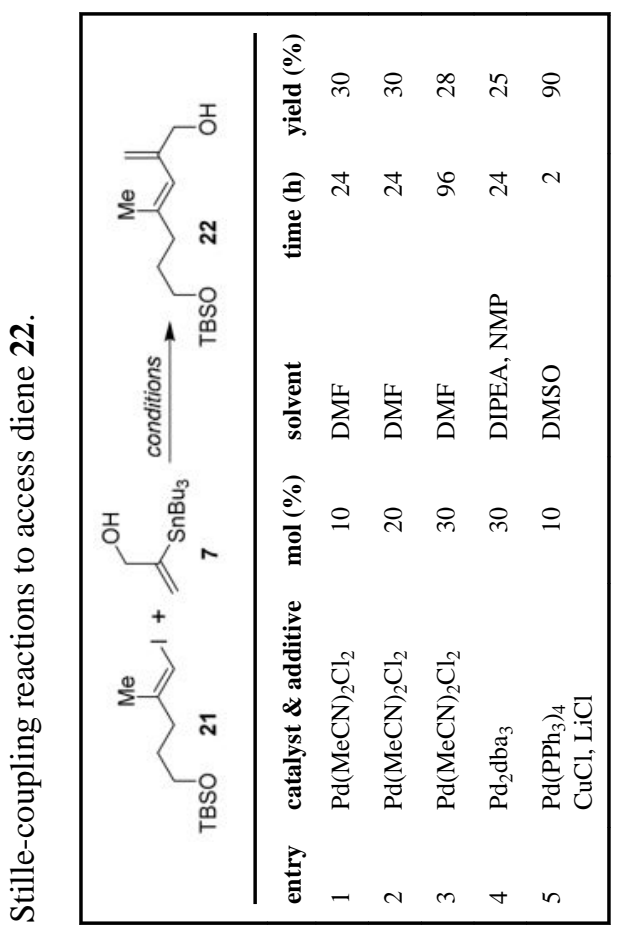

로을

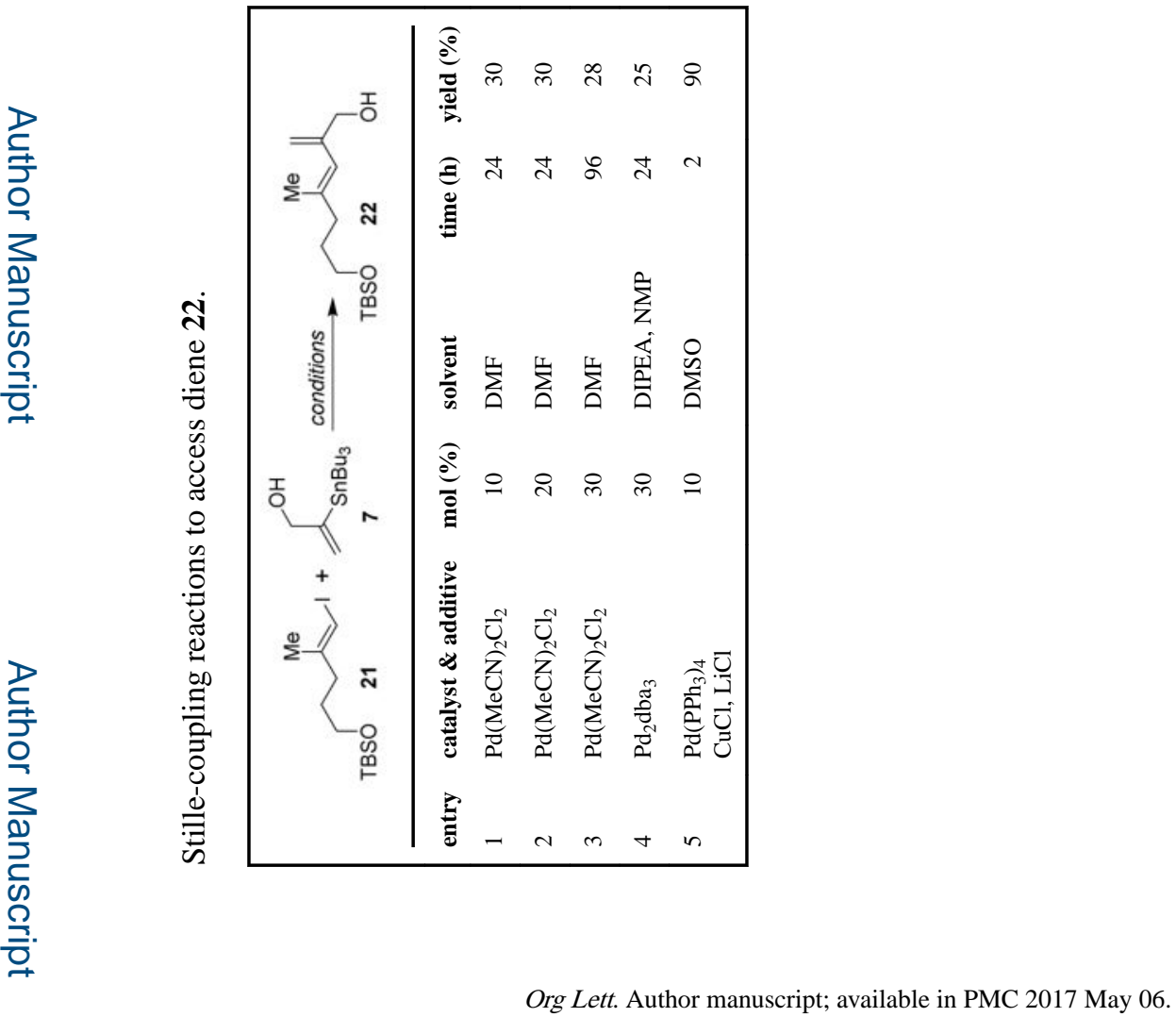

